\section{SOME RECENT PUBLICATIONS OF GEOLOGICAL SURVEYS.}

THE active Geological Survey of Great Britain has issued its "Summary of Progress for 1907 " (1908, price Is.), which is no mere departmental report, since it contains a number of original memoirs. One of these is by Dr. Flett, on the rocks styled mugearites, which may be described as dolerites rich in oligoclase and olivine, but poor in augite. These have now been found among the Carboniferous lavas of East Lothian and Midlothian, where they closely resemble Mr. Harker's original Cainozoic types from Skye. Two other memoirs deal usefully with new sections along English railways. Perhaps the most interesting feature of the general descriptions of the year's work is the insight given (p. 66, \&c.) into the progress of the survey of Mull, from which much that is new may be expected.

The full memoir on "The Small Isles of Inverness-shire (Rum, Canna, Eigg, Muck, \&c.)," by Messrs. Harker and Barrow, is now also published (Ig08, price $4 s .6 d$.). In chapter iii., the Mesozoic strata of Eigg and Muck are
Sheet 125 (1908, price 35.$)$. The accompanying map (Is. 6d.) was drawn up in 1907 , and includes the drifts, which here play no great part in the surface geology. The "solid" rocks range from Carboniferous. Liméstone up to Keuper marl, and almost all provide material of industrial value. Even the lead-mines in the north-west of the area show signs of revival. Messrs. Gibson and Wedd furnish an interesting sketch of the great variety of scenery to be met with in the country north of Derby. The term "Yoredale rocks" has been abandoned in this area (p. 8), but the typical "Pendleside series" has not as yet been traced. Numerous new observations are made on the coal-bearing strata, and the drifts are now described for the first time. In the north-cast of the area, certain esker-like mounds (p. r65) are referred to the action of the Irish Sea glacier, which sent out a lobe thus far into the Midlands.

Mr. W. A. E. Ussher describes "The Geology of the Quantock Hills and of Taunton and Bridgwater" (1908, price 2s.) in a memoir accompanying Sheet 295 (1907, price Is. $6 d$.). The map gives a picture of the great alluvial flat at Bridgwater, above which the Quantocks,

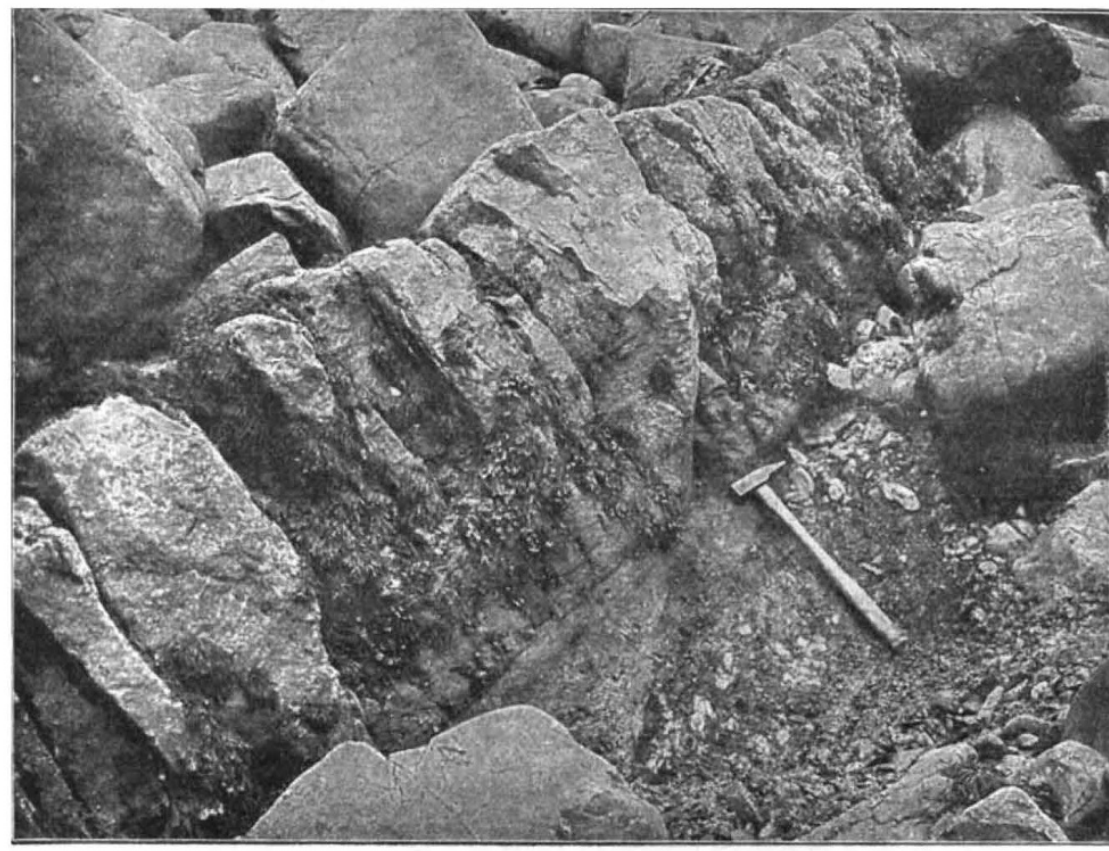

Photo.]

FIG, 1.-Cretaceous Sandstone resting on Oxfordian Strata, Laig Pay, Eigg formed of hard Devonian strata, rise boldly on the west. The occurrence of Carboniferous Limestone at Cannington Park, and of cherty Lower Culm-measures resting on Upper Devonian in the region to the south-west, gives rise to an interesting discussion (p. 33), in which it is urged that these two series are contemporaneous. Mr. H. B. Woodward adds a chapter on the Lower Lias near the Bristol Channel north of Williton.

The memoir on "The Geology of the Country around Oxford," by Messrs. Pocock, H. B. Woodward, and Lamplugh (1908, price 2s. $3^{d}$.), accompanies a specially arranged map with $\mathrm{Ox}$ ford in the centre (1908, price Is. $6 d$.). These publications are sure to have a rapid sale, and the colour-printed map, although it includes drifts, gives a very clear indication of the structure of the country. Mr. Lamplugh places the Shotover Sands (p. 66) as Wealden; on the east, near Great Milton, they are over-

dealt with: Upper Cretaceous sandstone, 2 fcet thick, has now been discovered in Eigg, resting on Oxfordian shales. Mr. Harker, following the lines of his masterly memoir on Skre, reports on the igneous series of Cainozoic age which forms the main mass of the islands. He lays much stress on the occurrence of intrusive sills, which have been regarded previously as lava-flows. Tuffs and gravels occur, and numerous true basaltic flows; but the author believes the famous mass of pitchstone that forms the Sgùrr of Eigg to be intrusive in the sills and lavas, and not a flow resting in an old valley-fioor. This matter has already been discussed before the Geological Society of London. We have similarly heard already of the Cainozoic gneisses of Rum, produced by the intrusion of granite into eucrite (p. 105); but here we have a complete account of them in which their similarity to some of the preCambrian gneisses is pointed out. It is, of course, well known from field-observations by Callaway and others that some of our ancient banded gneisses have also arisen from an intermingling of acid and basic igneous rocks.

The southern part of the Derbyshire and Nottinghamshire coalfield is dealt with in a memoir explanatory of lain by Gault, apparently without the intervention of marine Lower Greensand

$[A, G$. Stenhouse. strata. This unconformity has been noticed elsewhere (p. 75 ) by Dr. A. M. Davics. The plateau-drift, a deposit older than the highest alluvial terraces of the streams, is correlated (p. IO2) with the chalky boulder-clay of regions to the east. Might we not ask, in a memoir of such wide interest, for some of the photographic illustrations, connecting surface-features and geological structure, which are so liberally furnished by the survey for less accessible districts? Large parts of rural and industrial England still require adequate illustration. In this matter, colonial surveys are a bright example to us.

In the concluding part of the jahrbuch der k.k. geologischen Reichsanstalt for 190\%, Ivii. Band (1907), Dr. F. E. Suess describes (p. 793) the structure of the narrow Carboniferous basin of Rossitz, on the Bohemian and Moravian border. The Culm-measures and Devonian strata are unconformably overlain, and mostly concealed, by Upper Carboniferous and Permian beds, to many of which a desert origin is ascribed. Periodic floods swept down banks of pebbles, and some of the Carboniferous conglomerates are regarded as the remains of land-slides. The great intrusive masses of granite and diorite in the 
Brunn area to the east must have been covered by the older sediments, since they yield no pebbles to the conglomerates, and their present proximity is due to faulting.

In the succeeding part (lviii. Band, I Heft, 1908) Herr P. S. Richarz describes (p. I) the hills traversed by the Danube between Hainburg and Pozsóny (Pressburg), a region of the most romantic interest. His sections on pp. 31 and 32 recall the towers climbing up on both sides along the crags, and the narrow passage eastward into lands long subject to the Turk. Beneath the castles of Theben on the north and Hainburg on the south, Lias limestone rests on an old series of phyllites and schists. The crystalline character of the schists is attributed to the action of the intrusive granite of the Little Carpathians, and the alteration of the Lias points to a post-Jurassic age for this intrusion. The author does not wish to extend this conclusion to the Carpathians in general, since the granite of the High Tatra is known to be pre-Permian. $\mathrm{He}$ is a supporter of the potency of contact-metamorphism in producing types of rock previously attributed to dynamic action, and on p. 48 he connects the rock-sequence in the Hainburg area, through the Leitha range, with the Semmering region, where the metamorphosed Kossen beds recall the crystalline Lias of the Little Carpathians. Herr F. Broili (p. 49), in describing remains of the amphibian Sclerocephalus from the "Gaskohle" of Nürschan, in Bohemia, enters fully into the question of the age of this deposit, and concludes in favour of its being Upper Carboniferous rather than lowest Permian. Frič has previously treated it as Permian. Herr W. Hammer (p. 79) furnishes a detailed paper on the Ortler Group and the Ciavalatschkamm, which should appeal to climbers as well as to professed geologists. Divergent views have been held regarding the structure of this region, and the author was entrusted with the preparation of a detailed geological map, which will be published in I909. His conclusions are opposed to those of Termier, who would introduce the principles of "Nappismus" to explain the folding of this part of the eastern Alps (p. 194).

In the Verhandlungen of the same institute, Dr. Franz Kossmat (Nos. 2 and 3,1908, p. 69) describes the country on the Isonzo round Karfreit (Kobarid or Caporetto), a region rarely traversed by the modern traveller, though it lies on one of the highways to Trieste. An overthrust here brings Triassic dolomite above Flysch beds, which are probably of Cretaceous age. The Jurassic to Eocene floor of the basin of Flitsch, which is finely seen, surrounded by Triassic limestones, as one comes down from the Predil Pass, is regarded by the author as the nose of a synclinal pushed over into the Triassic area from the south-east. $\mathrm{He}$ has to resist the temptation of treating it as a

"Fenster" in this region of conspicuous overthrusts. In Nos. 5 and 6, I908, p. III, Herr Wegner, of Breslau, adds considerably to our knowledge of the mammalian fauna of Oppeln, in Silesia. He points out that Pliopithecus antiquus, though represented only by teeth and jaws, is so widely spread in the Upper Miocene of Europe that it may be regarded as a characteristic fossil.

In No. 7, Herr Petrascheck (p. 140) describes the relation of the Sudetic mass to the adjacent part of the Carpathians, and supports the views of Suess, with some minor modifications. He thus urges that pre-Miocene folding had much to do with the present structure of the Sudetic area.

The late Mr. T. Barron's memoir on "The Topography and Geology of the District between Cairo and Suez" has been issued by the Survey Department of the Finance Ministry of Egypt (Cairo, I907). It will be new to many who know the railway that runs close beside the Ismailia
Canal to learn that traces of a direct and older line lie to the south of it, in more broken country, and near the historic post-road. The great macadamised road is now becoming lost in sand. The rocks described from this desert region are Cretaceous and Cainozoic. On p. II there is a striking passage, in support of Prof. Lapworth's view of the migration of earth-folds as advancing crustwaves; the author traces a trough into a wave-crest and then into a succeeding trough, as he surveys the history of his district from Eocene to Middle Miocene times. Practically the same succession is seen in the Paris basin, and we wish that $\mathrm{Mr}$. Barron had been spared to state his views as to the further course of the wave that has controlled the deposits of Lower Egypt.

From the Geological Survey of India we have received Mr. Hayden's "Geology of Tsang and $\dot{U}$ in Central Tibet" (Memoirs, vol. xxxvi., part ii., I90 $\tilde{j}$ ). The foliated biotite-granite of the Himalayas is continued into this region, and is undoubtedly intrusive in Jurassic rocks, which cover the greater part of the area. The Eocene marine beds do not contain nummulites, and may be older than the nummulitic stage of other areas (p. $5^{6}$ ). The memoir includes photographic plates showing fine outcrops of strata on almost barren mountain sides. Part iii. of

.
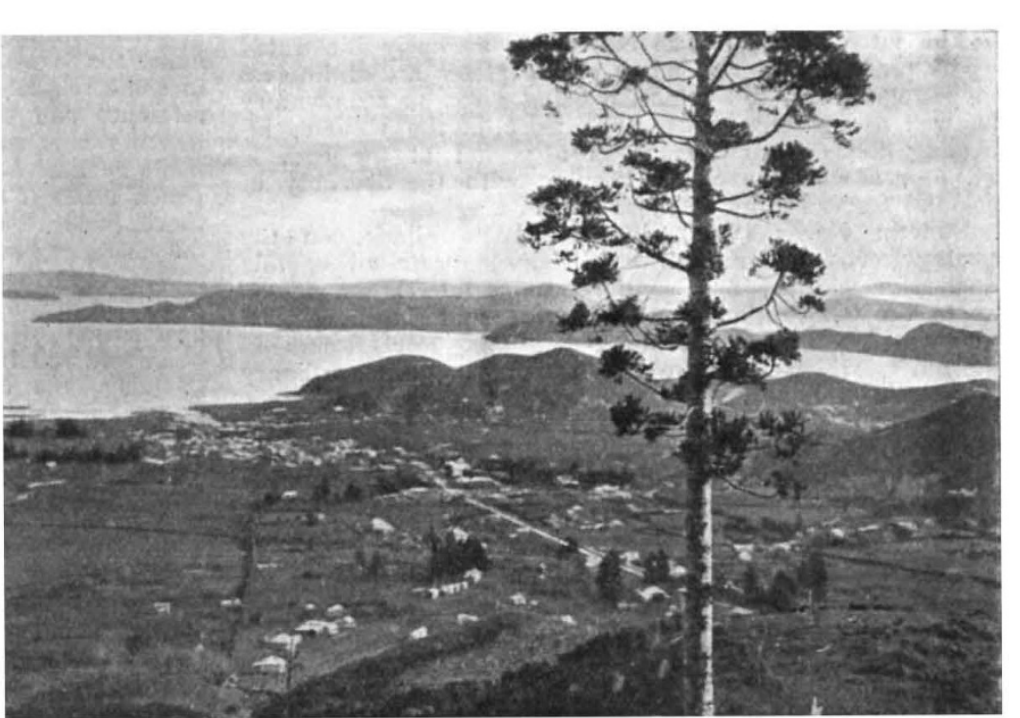
Photo.]
FIG. 2. - Beattie and Co., Auckland. Photo. $] W$. Beattie and Co., Auckland.
FIG. 2.-The Town of Coromandel, Auckland, situated on Recent Deposits at the foot of hills. formed of pre- $\int$ urassic sediments.

vol. xxxvi. of the Records of the same survey (rgo8, price I rupee) contains several palæontological papers, one of which, by Mr. Vredenburg, reviews the Cretaceous species of Orbitoides in India. Dr. Bleeck, of Munich (p. 164), describes the occurrence of corundum in metamorphic limestone in the Kachin Hills of Upper Burma. He urges that the crystalline limestone originated here, at any rate, by contact-alteration of a sediment, under conditions of pressure sufficient to produce corundum and to impart a foliation to the invading granite.

The Geological Commission of the Colony of the Cape of Good Hope, working under conditions of peculiar difficulty, has already issued in 1908 four large geological sheets of the map of the north-west area, including Mafeking, Vryburg, and Kimberley. These can be bought in London from Messrs. Wesley and Son, price $2 s .6 d$. each. The unconformity between the glacial Dwyka beds and the older rocks comes out well on Sheet $5^{\circ}$, and in Sheet $4^{2}$ we reach a district near Kimberley where the striated surfaces due to Permian ice are admirably seen in the field. The Twelfth Annual Report of the Commission, for r 1907 (1908), by Dr. A. W. Rogers and Mr. Du Toit, describes much of the area of the maps with characteristic clearness. An interesting example of "pillow lava," a much discussed type of flow, is described 
on p. 66. The superficial deposits of the dry region include much calcareous tufa, and recent quartzites appear as we go westward into the genuine desert.

Prof. T. W. Edgeworth David has issued the first part of his description of "The Hunter River Coal Measures, New South Wales" (Mem. Geol. Survey, N.S.W., r9o7, price $12 s .6 d$.). This memoir, forming a handsome quarto volume, explains the numerous coloured maps and sections that have been published under a separate cover. The plates will interest the practical miner as well as the geologist. The sedimentary rocks and typical fossils are here excellently illustrated. The limits of the Australian P'ermo-Carboniferous system are discussed (p. 3II); glacial beds, 200 feet thick (p. 32I), occur in the Lower Marine series, and ice-borne erratics have been dropped into the Upper Marine muds, which are indented by them (p. 197 and Plate xxiv.).

The New Zealand Geological Survey, in Bulletin No. 4 (1907), by Messrs. C. Fraser and J. H. Adams, describes the geology of the Coromandel subdivision, Auckland. This area includes the oldest goldfield in New Zealand, which is at present not particularly flourishing. The Hauraki mine, however, must have amply rewarded its original shareholders. The veins containing gold and silver, whether in the Jurassic and older sediments or in the Cainozoic andesites, are connected with the extrusion of the latter (p. 98). The bulletin is as finely illustrated as its predecessors, and many of the plates are of interest to petrographers, full attention being given to sedimentary as well as igneous rocks. The price of the volume, including four coloured maps in a pocket at the end, is $2 s$. $6 d$., a sum that is in keeping with the liberality of colonial Governments in these matters.

Bulletin No. 5 (1908), by Mr. James Park, on the geology of the Cromwell subdivision, forms an equally handsome volume, and contains some interesting details as to the distribution of gold-bearing material by glacial action. No natural sorting out of the gold occurs in moraines, which thus are less satisfactory than ordinary pockets in alluvium.

The Annual Report of the Geological Survey of Canada for 1904 was issued in 1906, but did not reach us until the present year. Bound up with it are several separately paged papers, including reports by $\mathrm{Mr}$. Keele and $\mathrm{Mr}$. Camsell on rivers in Yukon, and by Dr. G. A. Young on Mount Yamaska, in Quebec. The Yamaska mass affords a study in igneous differentiation, with basic "yamaskite" in the centre, graduating outwards into " essexite," and then into "akerite," with nearly 6o per cent. of silica. The Summary Report of the same survey for 1906 appeared in 1907 , and shows the wide range of the work, attention being especially directed to mineral resources and to the economic possibilities of new routes opened across the country. Mr. W. W. Leach's separately printed paper on the Telkwa River and vicinity, British Columbia (Geol. Surv. Canada, Ottawa, 190 $\bar{\gamma}$ ), shows the pioneer work that falls to the geologist, side by side with the miner, in this great Dominion.

Since our last article on "Geological Work in the United States." (NATURE, vol. Ixxviii., p. 282), we have received the annual report of the Geological Survey of New Jersey for 1907 (Trenton, I908), and vol. vi. of the Maryland Geological Survey, dated 1906. The former is distributed for the cost of postage, and includes an interesting and surprisingly, direct warning to would-be investors (p. 15) against speculators in the Portland cement industry. Mr. I. V. Lewis has written on the petrography of the Newark igneous rocks. His memoir (pp. 96-168 of the report). which is very fully illustrated, contains a description of certain inclusions of arkose in diabase (p. 134), which have assumed the composition and partly the structure of augite-granite. The green augite present has been probably derived from the igneous invader, but the defects of any chemical classification of rocks are emphasised more than ever when we learn that one of these altered masses should fall into the "dosodic subrang of the rang alaskase," and another into the "presodic subrang of the rang dacase." When Mr. Lewis shows us the origin of these rocks in the field, such nomenclature appears as a mere learned trifling. The basaltic lavas of the Watchung area are admirably described, and their zeolites are attributed to the action of "juvenile" waters during the cooling of the flows. The Maryland volume is, as usual, very handsome, but far too heavy for the hand. The whole physiography of the State is dealt with, and a general account of its geological structure follows. The first $25 \mathrm{I}$ pages, covering also the soils and meteorology, form, indeed, a popular and exact guide for any educated citizen. Mr. E. B. Mathews contributes a history of the origin of the counties of Maryland, occupying more than 150 of these weighty pages; we must presume that this, like the reports of the highway surveyors, finds its most fitting place within the green covers of this well-known geological series.

The Annual Report of the Iowa Geological Survey for 1906 (1907) deals extensively with Portland cement and with the rocks quarried for economic purposes in,the State. The analyses and tests of sedimentary building-stones have a petrographic as well as an engineering value, since these types of rock are apt to be neglected.

G. A. J. C.

\section{THREE VOLUMES ON NORTH SEA FISHERY INVESTIGATION.}

THE first of the volumes referred to below reports a meeting of the International Council named, held in London last year, and also contains accounts of numerous researches. Both parts possess features of, in some respects, unusual interest, to only a few of which reference can be made in the present brief notice. The meeting was memorable as the occasion of some remarks made by Earl Grey in the course of an address of welcome, which made it clear that the British Government intended to continue to support marine research in the interest of the fisheries, and looked favourably on international cooperation in the matter. Since the conference a committee has been appointed by the Treasury to inquire into the prosecution of such researches, has heard evidence, deliberated, and lately has made its recommendations, which include plans for the organisation of the work. There seems, therefore, every probability of British fishery research being placed on a permanent basis, and an opportunity has obviously occurred which, if wisely dealt with, may result in an important step in the application of biology to industry.

Another interesting announcement was that of Commander Drechsel, who stated that a convention had been arranged between Sweden and Denmark which would prevent the landing in these countries of undersized fish from the Kattegat, including its extra-territorial waters. This convention is said to be due to the results of research. The results in question appear to be embodied in the "Summary Report on the State of our Knowledge with Regard to Plaice and Plaice Fisheries," by Petersen, Garstang, and Kyle.

This summary, which is as able as it is concise, was prepared in response to a request of the Dutch and Danish Governments. It deals with very varied studies, and is backed by a formidable array of seventy-four tables. It recommends legislation against the landing of small plaice from the Kattegat, because these small fish are not fatally injured by the methods of fishing there employed, rarely leave the district, and increase in value with growth to an extent which amply compensates the fishery for their loss as small fish. The conditions in the North Sea are felt to be more complex, and for this area no legislation is recommended, though the report favours the transplantation of plaice to good feeding-grounds. An apparent discrepancy between the estimates of intensity of fishing and of its effects calls for mention. The intensity of fishing in the Kattegat is held to be greater than in the North Sea; yet while the evidence (described as " not large") points to a lowering of the average length of North Sea plaice, the weight per score of Kattegat plaice of above $25.6 \mathrm{~cm}$. length is not declining (Table III.). If North Sea fishing kills off the large plaice more quickly than nature replaces them, a fortiori the largest Kattegat

1 (I) "Rapports et Procès verhaux des Reunions. Conseil permanent international pour l'Exploration de la Mer." Vol. vii. Pp. xxxviii +314.

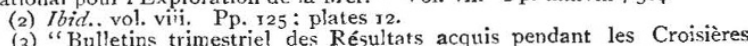
périodiques." Année rgct-7. No. 3. Pr. $33-95$; plates 9. 